\title{
Microstructural Modification and Characterization of Sericite
}

\author{
Yu Liang, Hao Ding *, Sijia Sun and Ying Chen \\ School of Materials Science and Technology, China University of Geosciences, No. 29 Xueyuan Road, \\ Haidian District, Beijing 100083, China; liangyuaadd@gmail.com (Y.L.); 1012122105@cugb.edu.cn (S.S.); \\ chenying@cugb.edu.cn (Y.C.) \\ * Correspondence: dinghao113@126.com or dinghao@cugb.edu.cn
}

Received: 24 August 2017; Accepted: 7 October 2017; Published: 16 October 2017

\begin{abstract}
Activated sericite was prepared by thermal modification, acid activation and sodium modification, and it was characterized by X-ray diffraction (XRD) analysis, differential scanning calorimetry (DSC), $\mathrm{N}_{2}$ adsorption test, thermo-gravimetric analysis (TGA), nuclear magnetic resonance (NMR), and scanning electron microscope (SEM). The results indicated that the crystallinity of raw sericite decreased after thermal modification; the pores with sizes between $5 \mathrm{~nm}$ to $10 \mathrm{~nm}$ of thermal-modified sericite have collapsed and the surface area increased after thermal modification. The dissolving-out amount of $\mathrm{Al}^{3+}$ reached ca. $31 \mathrm{mg} / \mathrm{g}$ in the optimal processing conditions during acid activation; cation exchange capacity (CEC) of acid-treated sericite increased to $56.37 \mathrm{mmol} / 100 \mathrm{~g} \mathrm{meq} / \mathrm{g}$ after sodium modification compared with that of raw sericite $(7.42 \mathrm{mmol} / 100 \mathrm{~g})$. The activated sericite is a promising matrix for clay-polymer nanocomposites.
\end{abstract}

Keywords: sericite; thermal modification; acid activation; sodium modification

\section{Introduction}

In recent years, great attention has been paid to clay-polymer nanocomposites due to their extraordinary properties. Compared with pure polymer, this category of composites usually exhibits higher moduli [1-3], larger strength and heat resistance [4], smaller gas permeability [5-7], better fire retardancy [8,9], higher ionic conductivity [10], and increased biodegradability of biodegradable polymers [11-13]. Clay-polymer nanocomposites are widely used in a range of key areas, such as aerospace, automobile, appliances, and electronics [14-16]. These properties depend heavily on the structure of nanocomposites, which is determined by the physical properties of clay mineral, such as its cation exchange capacity (CEC) which is used to quantify the excess negative charge of layered silicates and their capability to exchange ions. CEC is highly dependent on the nature of the isomorphous substitutions in the tetrahedral and octahedral layers.

The common layered silicates used for preparation of clay-polymer nanocomposites are 2:1 type (montmorillonite, vermiculite, and mica) and 1:1 type (kaolinite); the former is used much more frequently. Montmorillonite [17-22] and vermiculite [23-29] have been mostly investigated as the matrix materials for clay-polymer nanocomposites because of their swelling behavior and ion exchange properties.

Although sericite belongs to 2:1 clay minerals, it does not swell in water and has almost no ion exchange capacity. It can hardly be intercalated because it has a high layer charge density close to 1.0 equivalent per $\mathrm{O}_{10}(\mathrm{OH})_{2}$, which produces pretty strong electrostatic force [30]. This layer charge stems mainly from the substitution of $\mathrm{Al}^{3+}$ for $\mathrm{Si}^{4+}$ in tetrahedral sheet. Sericite is very fined squamous-structured muscovite, as one kind of mica family. It holds the advantages of high moduli, stable chemical property, high electrical insulation and good ultraviolet ray resistance [31-34]. Therefore, it is necessary to explore the preparation of an expandable sericite with relatively high CEC. 
The purpose of activation is to permanently reduce the layer charge of sericite and obtain a number of exchangeable cations. The physical and chemical modifications have long been used to activate clay and clay minerals, such as acid activation and thermal treatment. Salt modification, mechanical grinding [35,36] and swelling by the decomposition of hydrogen peroxide [37] are also usually employed. Poncelet and del Rey-Perez-Caballero [25,38] permanently reduced the global negative charge of the mineral layers by the combination of calcination and acid activation, and the resulting product (activated vermiculite/phlogopite mica) was successfully used as matrix in micro porous $18 \AA$ Al-pillared nanocomposites. They found that $\mathrm{Al}^{3+}$ in tetrahedral sheet could be partly dissolved out by the combination process and yet had an unremarkable effect on the structure of octahedral sheet. Furthermore, a well-swelled sericite with $80 \%$ exchangeable $\mathrm{K}^{+}$and a CEC of $110 \mathrm{mmol} / 100 \mathrm{~g}$ was obtained by Shih and Shen [32] by thermal modification and Li-hydrothermal treatment.

In this study, activated sericite was prepared by thermal modification, acid activation, and sodium modification. The X-ray diffraction (XRD) analysis, $\mathrm{N}_{2}$ adsorption test, nuclear magnetic resonance (NMR) and scanning electron microscope (SEM) were used to elucidate the effect of this process. From our study, it can be seen that thermal modification can reduce the layer charge and crystallinity of sericite. Acid activation can dissolve both the octahedral and tetrahedral $\mathrm{Al}^{3+}$ out and reduce its layer charge and sodium modification can finally improve the CEC value of sericite. Therefore, the whole modification process can make sericite more suitable for polymer-clay nanocomposites.

\section{Materials and Methods}

\subsection{Materials}

The raw sericite $\left(\mathrm{S}_{0}\right)$ was obtained from Anhui province, China. Its mean size is about $10 \mu \mathrm{m}$. CEC of $\mathrm{S}_{0}$ is $7.42 \mathrm{mmol} / 100 \mathrm{~g}(0.07 \mathrm{meq} / \mathrm{g})$. The quantitative analysis of the raw material showed that the purity of raw sericite is $93.2 \%$, with $6.8 \%$ of quartz. Ruling out the influence of quartz, the chemical composition of $\mathrm{S}_{0}$ is listed in Table 1. The chemical formula is $\left(\mathrm{K}_{0.79} \mathrm{Na}_{0.11} \mathrm{Ca}_{0.01}\right)\left(\mathrm{Al}_{1.64} \mathrm{Ti}_{0.02} \mathrm{Fe}_{0.18} \mathrm{Mg}_{0.24}\right)\left(\mathrm{Al}_{0.92} \mathrm{Si}_{3.08}\right) \mathrm{O}_{10}(\mathrm{OH})_{2}$.

Table 1. Chemical composition of the original sericite.

\begin{tabular}{cccccccccccc}
\hline Composition & $\mathrm{SiO}_{2}$ & $\mathrm{Al}_{2} \mathrm{O}_{3}$ & $\mathrm{Fe}_{2} \mathrm{O}_{3}$ & $\mathrm{TiO}_{2}$ & $\mathrm{~K}_{\mathbf{2}} \mathrm{O}$ & $\mathbf{N a}_{2} \mathrm{O}$ & $\mathrm{CaO}$ & $\mathbf{M g O}$ & $\mathbf{S O}_{3}$ & L.O.I & Total \\
\hline Content (mass \%) & 45.71 & 28.32 & 3.04 & 0.35 & 8.09 & 0.71 & 0.10 & 2.12 & 0.075 & 4.47 & 99.555 \\
\hline
\end{tabular}

\subsection{Preparation}

A certain amount of raw sericite $\left(\mathrm{S}_{0}\right)$ was put into $\mathrm{Al}_{2} \mathrm{O}_{3}$ crucibles and heated between 500 and $1000^{\circ} \mathrm{C}$ in muffle for 1 to $3 \mathrm{~h}$ and cooled to room temperature naturally. After that, the thermally-treated product $\left(\mathrm{S}_{1}\right)$ was stirred with different kinds and concentrations of acid between 60 to $95{ }^{\circ} \mathrm{C}$ in thermostatic water bath for $4 \mathrm{~h}$. The acid-treated product $\left(\mathrm{S}_{2}\right)$ was washed, filtrated, and dried at $80^{\circ} \mathrm{C}$. In this study, experiment term was based on an orthogonal term array experimental design $\left(\mathrm{OA}\left(9,3^{4}\right)\right)$ where the following four variables were analyzed: the kinds of acid (factor A), acid concentration (factor B), reaction temperature (factor C) and reaction time (factor D). Finally, sodium chloride was added to react with $S_{2}$ in round bottomed flask. The sodium modified product $\left(\mathrm{S}_{3}\right)$ was obtained by mixing, washing, centrifuging, and drying at $80^{\circ} \mathrm{C}$. The orthogonal experiment term method $\left(\mathrm{OA}\left(9,3^{3}\right)\right)$ was used to find three optimal parameters: concentration of $\mathrm{Na}^{+}$(factor $\left.\mathrm{A}\right)$, reaction temperature (factor B) and reaction time (factor C).

\subsection{Characterization}

The X-ray diffraction patterns were obtained on a Rigaku Rotaflex X-ray powder diffractometer (Rigaku, Tokyo, Japan), employing $\mathrm{Cu} \mathrm{K} \alpha$ radiation, $40 \mathrm{kV}, 100 \mathrm{~mA}$. The X-ray diffraction (XRD) patterns in the $2 \theta$ range from $3^{\circ}-70^{\circ}$ were collected at $4^{\circ} / \mathrm{min}$. Simultaneous collection of DSC and 
TGA signals was carried out using a SDT Q600 analyzer (TA, New Castle, DE, USA) under air flow and heated from room temperature to $1100{ }^{\circ} \mathrm{C}$ at $10{ }^{\circ} \mathrm{C} / \mathrm{min}$. The BET surface area of the samples was determined by $\mathrm{N}_{2}$ adsorption by using NOVA4000 equipment (Quantachrome, Boynton Beach, FL, USA). Prior to $\mathrm{N}_{2}$ adsorption, the samples were evacuated at $473 \mathrm{~K}$ under vacuum for $4 \mathrm{~h}$. The pore size distribution was calculated using the BJH method. ${ }^{27} \mathrm{Al} \mathrm{NMR} \mathrm{spectrum}(130.327 \mathrm{~Hz})$ was recorded on a Bruker Avance III spectrometer (Bruker, Karlsruher, Germany). The dwell time is $0.01 \mathrm{~s}$ and the rotational speed is $6000 \mathrm{rpm}$.

\section{Results and Discussion}

\subsection{Thermal Modification}

A slight weight loss is observed in the TG curve at low temperature (Figure 1), which is attributed to absorbed surface water. There is a mass loss in the TG curve at $3 \%$ between 670 and $841^{\circ} \mathrm{C}$ according to the DSC curve peak at the same temperature, which indicates that the hydroxyl groups were lost with increasing temperature during thermal modification.

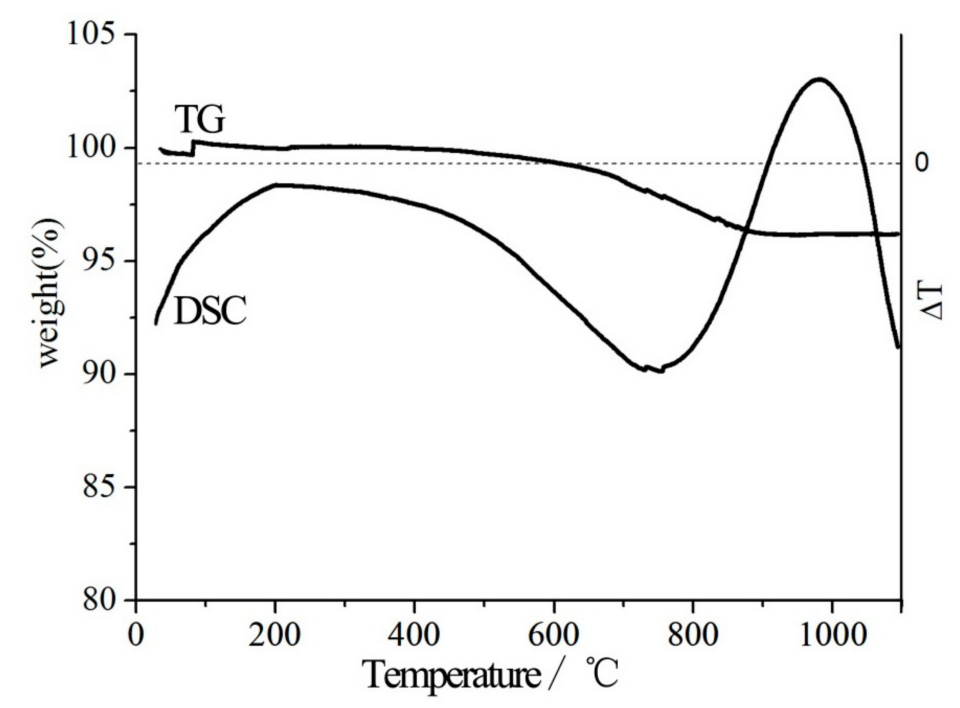

Figure 1. TG and DSC curves of $S_{0}$.

The XRD patterns of sericite which were activated at different temperatures are shown in Figure 2. The intensities of major reflections decreased gradually as the temperature increased and finally almost disappeared at $1100^{\circ} \mathrm{C}$, which suggested that the mica-type phase persisted when the temperature was lower than $900{ }^{\circ} \mathrm{C}$. The phase transformation would occur and its crystal integrity would be destroyed gradually when heated at $1000{ }^{\circ} \mathrm{C}$. The lattice activated degree can be judged by lattice distortion level. The relationship between lattice distortion level, crystal size, full width at half maximum (FWHM) of reflections and diffraction angle can be calculated by Scherrer's equation:

$$
\mathrm{B} \cos \theta=\mathrm{K} \lambda / \mathrm{D}+4 \Delta \mathrm{d} \sin \theta / \mathrm{d}
$$

where $\mathrm{B}$ is FWHM; $\theta$ is diffraction angle; $\mathrm{K}$ is the form factor, which is close to $1 ; \lambda$ is the wavelength of $\mathrm{X}$-ray; $\mathrm{D}$ is the crystal lattice size; $\mathrm{d}$ is the distance between crystal planes; $\Delta \mathrm{d}$ is the average deviation between the distance of reflecting planes under study and the mean value $\mathrm{d}$. $4 \Delta \mathrm{d} / \mathrm{d}$ shows the level of lattice distortion. The larger the value, the higher the distortion level, and vice versa. In this part, Bcos $\theta$ and $\sin \theta$ of different products which reflect the lattice distortion level were calculated from XRD data. The slope $(4 \Delta \mathrm{d} / \mathrm{d})$ and intercept $(\mathrm{k} \lambda / \mathrm{d})$ were obtained by linear fitting, using $\sin \theta$ as $X$ axis and $B \cos \theta$ as $Y$ axis. The obtained values were summarized in Table 2 . 


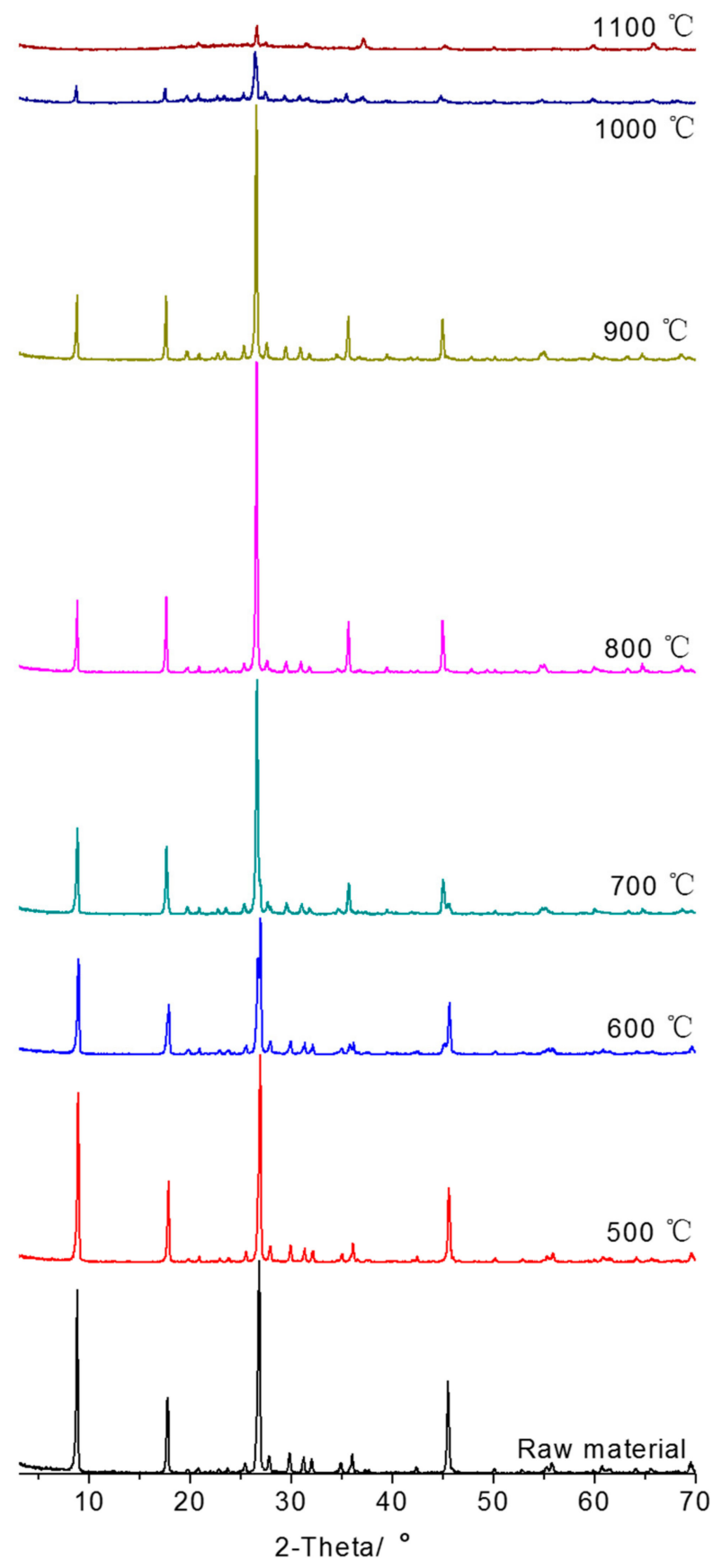

Figure 2. XRD patterns of sericite after heating at different temperatures.

Table 2. Relation between $B \cos \theta$ and $\sin \theta$ of sericite activated at different temperatures in the (002) reflection.

\begin{tabular}{cccccccc}
\hline Temperature $\left({ }^{\circ} \mathbf{C}\right)$ & Raw Material & $\mathbf{5 0 0}$ & $\mathbf{6 0 0}$ & $\mathbf{7 0 0}$ & $\mathbf{8 0 0}$ & $\mathbf{9 0 0}$ & $\mathbf{1 0 0 0}$ \\
\hline $\mathrm{k} \lambda / \mathrm{D}$ & 0.2146 & 0.2259 & 0.3059 & 0.3797 & 0.2937 & 0.2128 & 0.1938 \\
$4 \Delta \mathrm{d} / \mathrm{d}$ & 0.0118 & -0.0381 & -0.1363 & -0.1631 & -0.1674 & -0.1372 & -0.0407 \\
\hline
\end{tabular}

As shown in Table 2, the value of $4 \Delta \mathrm{d}$ / $\mathrm{d}$ of raw sericite is 0.0118 (close to 0 ), which is a proof of little lattice distortion. As the temperature increased, the absolute value of $4 \Delta \mathrm{d} / \mathrm{d}$ of the thermally-treated product increased gradually, reaching the largest value at $800{ }^{\circ} \mathrm{C}$. The line's slope starts to decrease at $900{ }^{\circ} \mathrm{C}$, follows by an even larger decrease at $1000^{\circ} \mathrm{C}$. The results above demonstrate that the best 
activated temperature is $800^{\circ} \mathrm{C}$ (with the same holding time). The loss of crystallinity is evaluated using the FWHM index (Table 3). Heating at $800{ }^{\circ} \mathrm{C}$ got the largest FWHM, which is a sign of the most lattice defects and distortion.

The raw sericite samples were heated at $800{ }^{\circ} \mathrm{C}$ and preserved for $1 \mathrm{~h}, 2 \mathrm{~h}$, and $3 \mathrm{~h}$. The XRD patterns are shown in Figure 3. The values of $k \lambda / D$ and $4 \Delta d / d$ extracted from the XRD data are shown in Table 4 . The absolute value of $4 \Delta \mathrm{d} / \mathrm{d}$ of sericite with a holding time of $1 \mathrm{~h}$ is much higher than that of raw material. When the holding time increased to $2 \mathrm{~h}$ or more, the slope decreased. The potential reason is that the increasing holding time make the unobvious preferential orientation of flakes caused by lattice distortion increase. Therefore, the best preservation time is $1 \mathrm{~h}$.

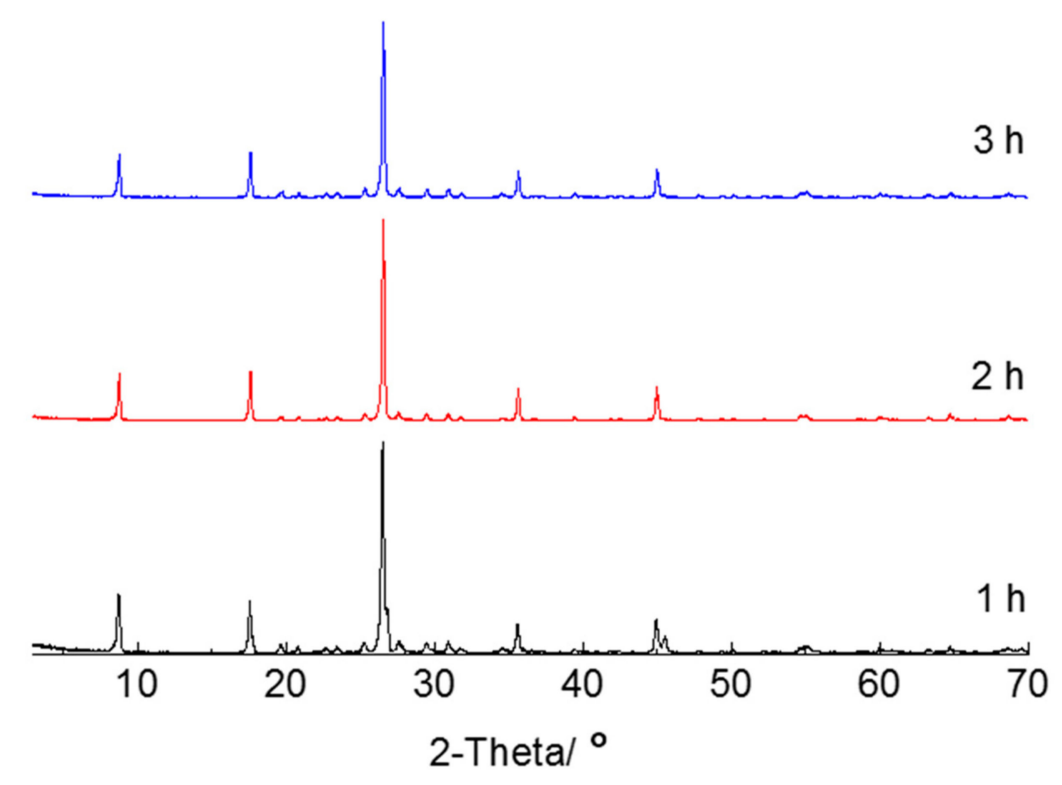

Figure 3. XRD patterns of sericite with different holding time at $800{ }^{\circ} \mathrm{C}$.

Table 3. FWHM index for raw material and thermal-modified products in the (002) reflection.

\begin{tabular}{cc}
\hline Samples & FWHM $\left(^{\circ}\right)$ \\
\hline $\mathrm{S}_{0}$ & 0.137 \\
$\mathrm{~S}_{1}\left(500^{\circ} \mathrm{C}\right)$ & 0.138 \\
$\mathrm{~S}_{1}\left(600^{\circ} \mathrm{C}\right)$ & 0.168 \\
$\mathrm{~S}_{1}\left(700^{\circ} \mathrm{C}\right)$ & 0.173 \\
$\mathrm{~S}_{1}\left(800^{\circ} \mathrm{C}\right)$ & 0.174 \\
$\mathrm{~S}_{1}\left(900^{\circ} \mathrm{C}\right)$ & 0.141 \\
$\mathrm{~S}_{1}\left(1000^{\circ} \mathrm{C}\right)$ & 0.132 \\
$\mathrm{~S}_{1}\left(1100^{\circ} \mathrm{C}\right)$ & - \\
\hline
\end{tabular}

Table 4. Relation between $B \cos \theta$ and $\sin \theta$ of sericite with different holding time.

\begin{tabular}{ccccc}
\hline Holding Time (h) & Raw Material & $\mathbf{1}$ & $\mathbf{2}$ & $\mathbf{3}$ \\
\hline $\mathrm{k} \lambda / \mathrm{D}$ & 0.2146 & 0.4287 & 0.2937 & 0.2277 \\
$4 \Delta \mathrm{d} / \mathrm{d}$ & 0.0118 & -0.2848 & -0.1674 & -0.1026 \\
\hline
\end{tabular}

$\mathrm{N}_{2}$ physisorption measurements have also been performed on both $S_{0}$ and $S_{1}$ (Figure 4). It can be seen that after thermal modification, the pores with sizes between $5 \mathrm{~nm}$ to $10 \mathrm{~nm}$ of thermally-modified sericite have collapsed. The surface area of $S_{0}$ is $14.653 \mathrm{~m}^{2} / \mathrm{g}$, while the surface area of $S_{1}$ is $16.579 \mathrm{~m}^{2} / \mathrm{g}$, which means thermal modification increased the activity of sericite. 

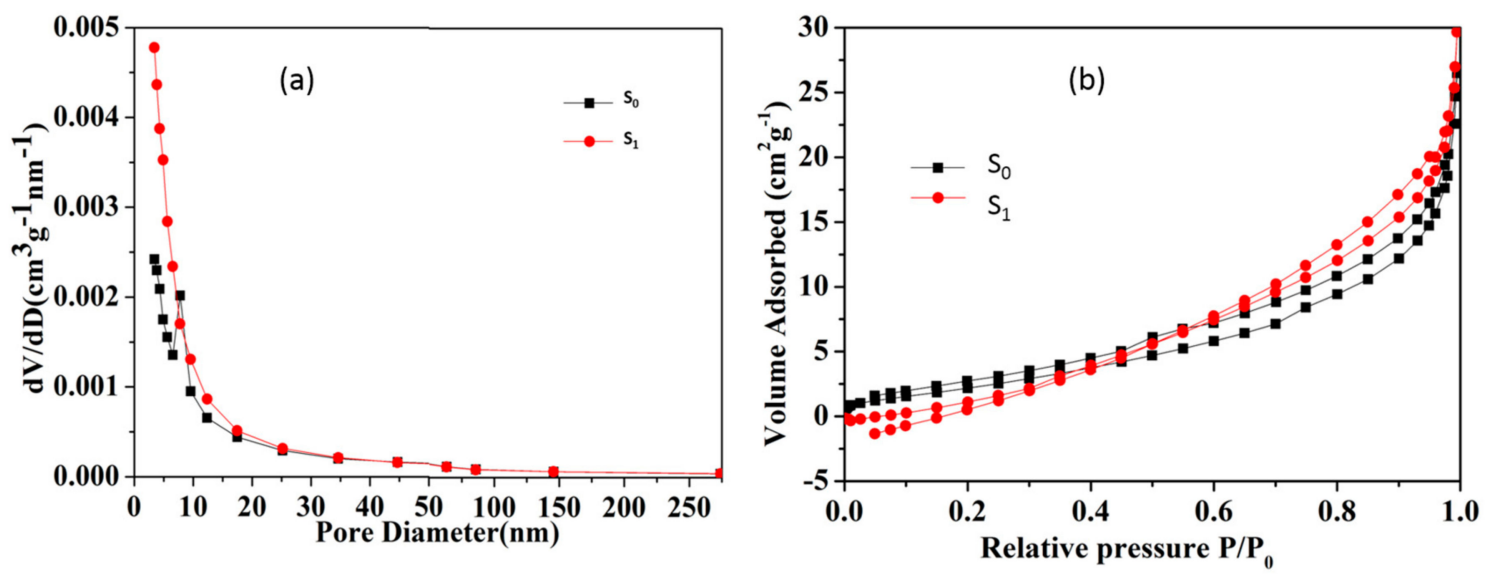

Figure 4. (a) Pore diameter distribution of raw sericite $\left(\mathrm{S}_{0}\right)$ and thermal-activated sericite $\left(\mathrm{S}_{1}\right)$; (b) the isotherm of $\mathrm{N}_{2}$ adsorption-desorption on sericite before and after thermal modification.

\subsection{Acid Activation}

According to the research of Poncelet and del Rey-Perez-Caballero [25] on the activation of vermiculite and phlogopite, the combination of acid treatment and heat treatment was employed to modify the microstructure of sericite. As a result, $\mathrm{Al}^{3+}$ was dissolved out and the negative layer charge was reduced, which enables sericite to take on an ion exchange capacity. The results of acid activation were evaluated by dissolving-out an amount of $\mathrm{Al}^{3+}$. The larger the dissolving-out amount of $\mathrm{Al}^{3+}$, the better the effect of acid activation.

The main four factors, kinds of acid (factor A), acid concentration (factor B), reaction temperature (factor C), and reaction time (factor D) were researched and each control parameter has three experimental levels (Table 5) [39,40].

Table 5. Design and results of the orthogonal experiment of acid treatment of sericite ${ }^{\mathrm{a}}$.



The optimal values of different factors determined with reference to Table 5 are as follows: nitric acid, $5 \mathrm{~mol} / \mathrm{L}, 95^{\circ} \mathrm{C}, 5 \mathrm{~h}$. In addition, the factors' levels of significance are as follows: reaction temperature $>$ acid concentration $>$ reaction time $>$ type of acid. 
Figure 5 shows the single effect of each factor on acid activation. A higher reaction temperature helped to dissolve $\mathrm{Al}^{3+}$ out. When temperature was low, the reaction system could not obtain enough power, so only a small amount of $\mathrm{Al}^{3+}$ dissolved out. The dissolving-out amount of $\mathrm{Al}^{3+}$ increased with the acid concentration, which means the higher the $\mathrm{H}^{+}$concentration, the better the result. However, when the acid concentration is ultrahigh, the layered structure would, conceivably, be seriously destroyed, which is not good for activation of sericite. Additionally, nitric acid is more effective on acid activation than the other two, although the kind of acid is not the most significant factor.

NMR analysis was done after acid activation. The range of chemical shift $(\delta)$ of $\mathrm{Al}$ is $450 \mathrm{ppm}$. Generally, $\delta$ of octahedral $\mathrm{Al}\left(\mathrm{Al}_{\mathrm{o}}\right)$ species and tetrahedral $\mathrm{Al}\left(\mathrm{Al}_{\mathrm{t}}\right)$ species is -10 to $10 \mathrm{ppm}$ and 50-70 ppm, respectively. Therefore, ${ }^{27} \mathrm{~A} 1 \mathrm{NMR}$ is employed to distinguish the two kinds of $\mathrm{Al}$ in clay. As shown in Figure $6, \delta$ of $\mathrm{Al}_{\mathrm{t}}$ and $\mathrm{Al}_{\mathrm{o}}$ of $\mathrm{S}_{0}$ was 71.4 (spinning sidebands were 118 and 25, respectively), and 4.0 (sidebands were 50 and -42 , respectively), both of which were similar to theoretical values. The counterparts of $S_{2}$ turned to be 67.5 and 4.0 , respectively.



(a)

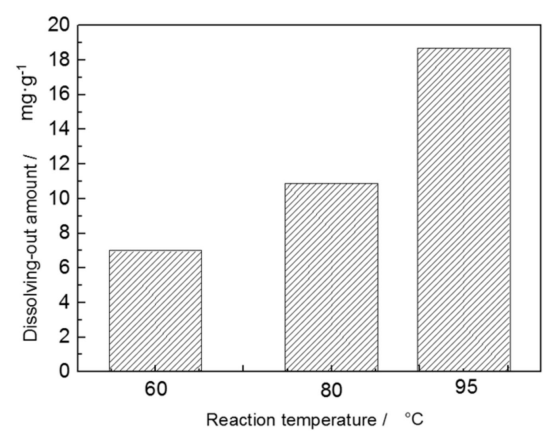

(c)

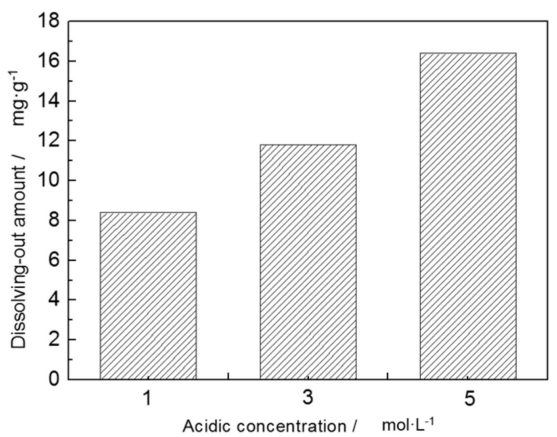

(b)

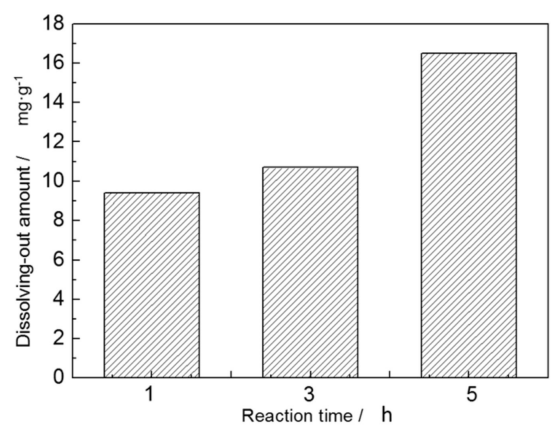

(d)

Figure 5. Effect of (a) kinds of acid; (b) acid concentration; (c) reaction temperature; and (d) reaction time on dissolving-out amount of $\mathrm{Al}^{3+}$.

The sharp peaks in ${ }^{27} \mathrm{~A} 1 \mathrm{NMR}$ is usually the sign of short range order in $\mathrm{Al}$, while broad peaks signal short range disorder. The peaks of $\mathrm{S}_{0}$ in ${ }^{27} \mathrm{Al}$ NMR spectrum are sharper than those of $\mathrm{S}_{2}$, which indicate that the layered structure become more disordered. The peak intensities of $\mathrm{Al}_{\mathrm{t}}$ and $\mathrm{Al}_{\mathrm{o}}$ of $\mathrm{S}_{2}$ decrease by $34 \%$ and $32 \%$, respectively, as compared with those of $S_{0}$, which suggest that $\mathrm{Al}_{t}$ and $\mathrm{Al}_{\mathrm{o}}$ are both dissolved out.

The relative content of $\mathrm{Al}_{\mathrm{t}}$ in $\mathrm{S}_{2}$ increased, and yet the peak width increased, which signaled an uneven distribution of $\mathrm{Al}_{\mathrm{t}}$. On the contrary, the relative content of $\mathrm{Al}_{\mathrm{o}}$ decreased, and yet the peak width decreased, which is a sign of even distribution of $\mathrm{Al}_{\mathrm{o}}$. This phenomenon can be explained by the decrease of layer charges that leads to a higher order degree of $\mathrm{Al}_{\mathrm{O}}$ [41]. The ratio of $\mathrm{Al}_{\mathrm{t}}$ to $\mathrm{Al}_{\mathrm{o}}$ decreased after acid treatment from 6.25:10 to 5.82:10, which means acid-treated sericite is more suitable for the ion exchanges in the next step. 


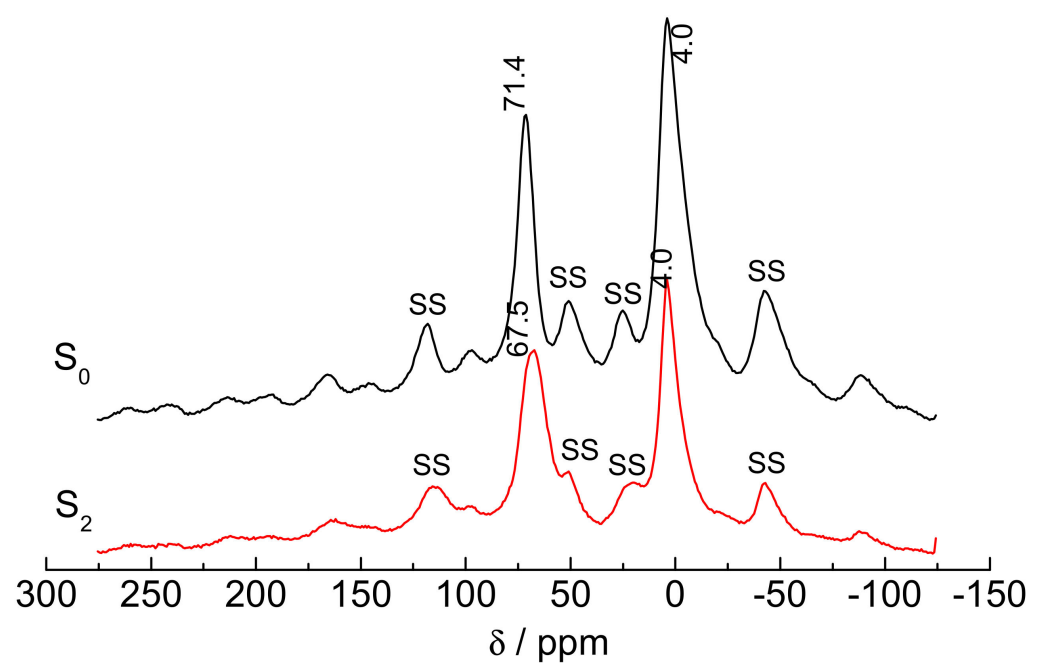

Figure 6. ${ }^{27} \mathrm{Al}$ NMR spectrums of $\mathrm{S}_{0}$ and $\mathrm{S}_{2}$ (SS means "spinning sidebands").

\subsection{Sodium Modification}

The results of sodium modification are evaluated by CEC. The larger the CEC value, the better the sodium modification result. Detailed sodium modification conditions are listed in Table 6. It can be seen that the optimal sodium modification conditions are as follows: supersaturated solution of sodium chloride, $95^{\circ} \mathrm{C}, 3 \mathrm{~h}$. The factors' levels of significance are as follows: $\mathrm{Na}^{+}$concentration > reaction temperature $>$ reaction time. The single effect of each factor on sodium modification is shown in Figure 7, which indicates that higher concentration of $\mathrm{Na}^{+}$and higher reaction temperature are of great benefit to the CEC of $S_{3}$.

The interlayer potassium cation twelve coordinates with two aspectant hexagonal holes created by the $\mathrm{Si} / \mathrm{Al}$ tetrahedral sheet, and is able to fit the two holes very tightly between the layers. Therefore, potassium cation and two adjacent tetrahedron sheets are bonded together closely by the electrostatic attraction. Consequently, it is hard for $\mathrm{K}^{+}$to be exchanged by $\mathrm{Na}^{+}$. However, the combination of thermal modification and acid activation made the exchange possible, which was due to the activation of lattice. $\mathrm{Na}^{+}$has the superiority of the smaller hydrated ionic radius and lower hydrated energy compared with those of $\mathrm{K}^{+}$. The higher reaction osmotic pressure was applied by the higher concentration of $\mathrm{Na}^{+}$, and higher reaction temperature made ions turn to be more active. Therefore, higher concentration of $\mathrm{Na}^{+}$and reaction temperature would benefit sodium modification. Additionally, the exchange of $\mathrm{Na}^{+}$for $\mathrm{K}^{+}$was in the state of dynamic equilibrium. Therefore, longer reaction time has no effect on the CEC of $\mathrm{S}_{3}$. Compared our study with the study of Shih, we used different treatment methods (we used Na-hydrothermal treatment while they used Li-hydrothermal treatment) at different temperatures (we used $60-95^{\circ} \mathrm{C}$ while they used $90-270{ }^{\circ} \mathrm{C}$ ). This is why our final CEC value $(56.37 \mathrm{mmol} / 100 \mathrm{~g})$ is lower than theirs $(110 \mathrm{mmol} / 100 \mathrm{~g})$.

The XRD patterns of raw material and activated products $\left(\mathrm{S}_{1}, \mathrm{~S}_{2}\right.$, and $\left.\mathrm{S}_{3}\right)$ prepared at the optimal conditions are shown in Figure 8, and the loss of crystallinity is evaluated using the FWHM index (Table 7). The decrease of reflection intensities of $S_{1}$ was caused by the removal of the hydroxyl water of raw material corresponding to the increase of FWHM of $S_{1}$. After acid activation, the reflection intensities and crystallinity of $S_{2}$ further decreased, which was a sign of more lattice defects and larger lattice distortion. Compared with the pattern of $S_{2}$, the interlayer space of $S_{3}$ decreased slightly, which was due to the exchange of $\mathrm{Na}^{+}$for $\mathrm{K}^{+}$between layers. However, sodium modification led to a better crystallinity of $S_{3}$ than that of $S_{2}$. This may be due to the fact that $\mathrm{Na}^{+}$balanced the change of layer charge of $S_{2}$ caused by acid activation, and the crystal structure of $S_{2}$ was repaired to some extent. 


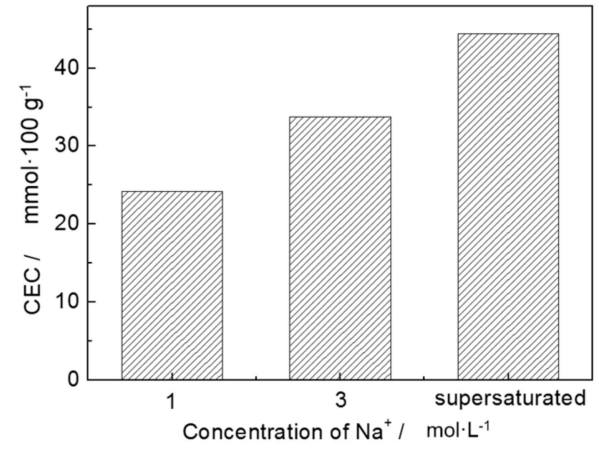

(a)

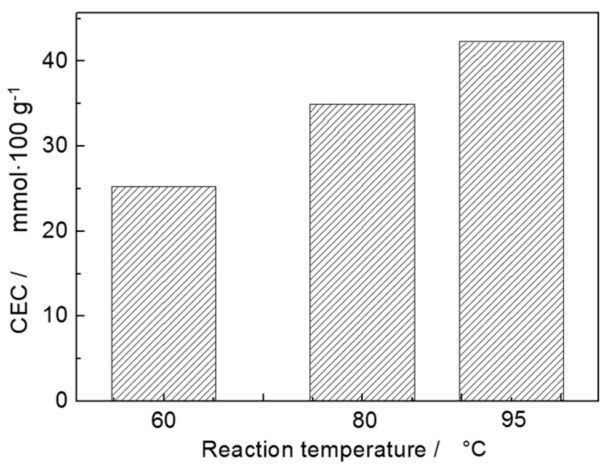

(b)



(c)

Figure 7. Effect of (a) concentration of $\mathrm{Na}^{+} ;(\mathbf{b})$ reaction temperature; and (c) reaction time on CEC.

Table 6. Design and results of the orthogonal experiment of sodium modification of sericite.

\begin{tabular}{|c|c|c|c|c|}
\hline \multirow[b]{2}{*}{ Trial No. } & \multicolumn{3}{|c|}{ Factors } & \multirow{2}{*}{$\begin{array}{c}\text { Results } \\
\text { CEC (mmol/100 g) }\end{array}$} \\
\hline & $\begin{array}{l}\text { Concentration of } \\
\mathrm{Na}^{+} A(\mathrm{~mol} / \mathrm{L})\end{array}$ & $\begin{array}{c}\text { Reaction Temperature } \\
\qquad B\left({ }^{\circ} \mathrm{C}\right)\end{array}$ & $\begin{array}{l}\text { Reaction Time } C \\
\text { (h) }\end{array}$ & \\
\hline 1 & 1 & 60 & 1 & 15.76 \\
\hline 2 & 1 & 80 & 3 & 27.24 \\
\hline 3 & 1 & 95 & 5 & 29.70 \\
\hline 4 & 3 & 60 & 3 & 25.36 \\
\hline 5 & 3 & 80 & 5 & 35.24 \\
\hline 6 & 3 & 95 & 1 & 40.76 \\
\hline 7 & Supersaturated & 60 & 5 & 34.62 \\
\hline 8 & Supersaturated & 80 & 1 & 42.34 \\
\hline 9 & Supersaturated & 95 & 3 & 56.37 \\
\hline $\mathrm{K}_{1, \mathrm{j}}$ & 72.70 & 75.24 & 98.86 & - \\
\hline $\mathrm{K}_{2, \mathrm{j}}$ & 101.36 & 104.82 & 108.97 & - \\
\hline $\mathrm{K}_{3, \mathrm{j}}$ & 133.33 & 126.83 & 99.56 & - \\
\hline $\mathrm{k}_{1, j}$ & 24.23 & 25.25 & 32.95 & - \\
\hline$k_{2, j}$ & 33.79 & 34.94 & 36.32 & - \\
\hline$k_{3, j}$ & 44.44 & 42.28 & 32.19 & - \\
\hline$R_{j}$ & 20.21 & 17.03 & 4.13 & - \\
\hline
\end{tabular}


Table 7. FWHM index for raw material and activate products in the (002) reflection.

\begin{tabular}{cc}
\hline Samples & FWHM $\left.^{\circ}\right)$ \\
\hline $\mathrm{S}_{0}$ & 0.208 \\
$\mathrm{~S}_{1}$ & 0.226 \\
$\mathrm{~S}_{2}$ & 0.720 \\
$\mathrm{~S}_{3}$ & 0.452 \\
\hline
\end{tabular}

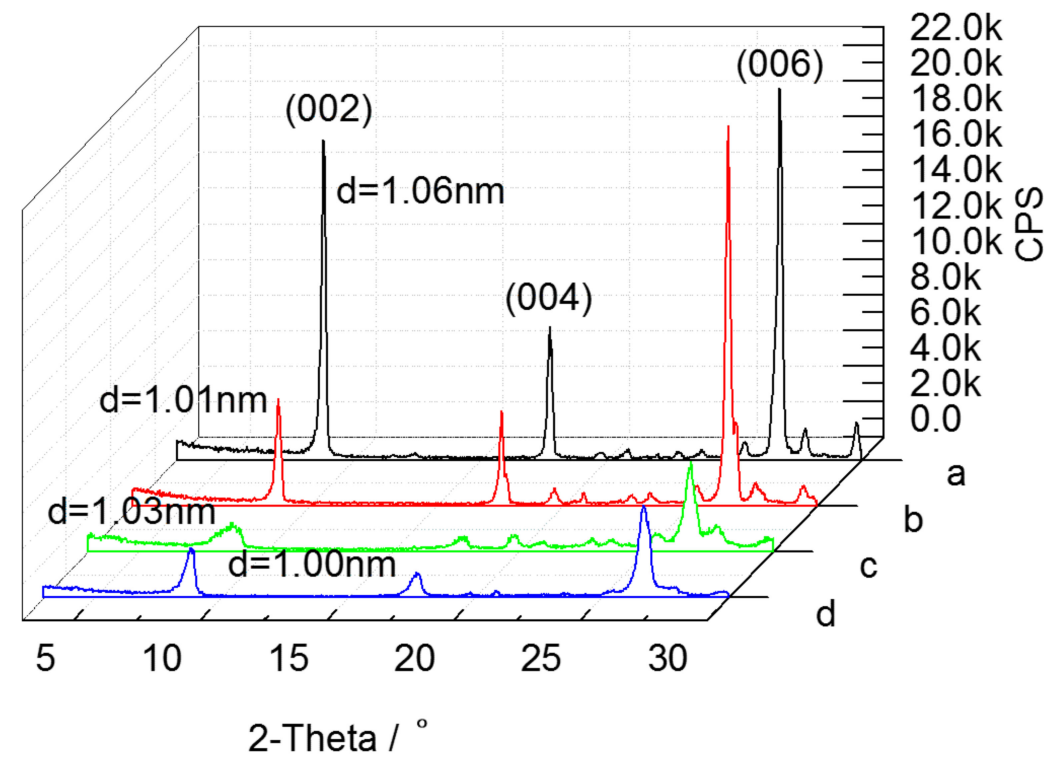

Figure 8. XRD patterns of (a) $\mathrm{S}_{0} ;\left(\right.$ b) $\mathrm{S}_{1} ;$ (c) $\mathrm{S}_{2}$; and (d) $\mathrm{S}_{3}$.

From SEM images, it can be seen that $\mathrm{S}_{0}$ has smooth surfaces, sharp fringed flakes, and uniform particle size (Figure 9). The SEM images of $S_{1}, S_{2}$, and $S_{3}$ clearly indicate that the mica-type phase of sericite persists while the particle surfaces become rougher.

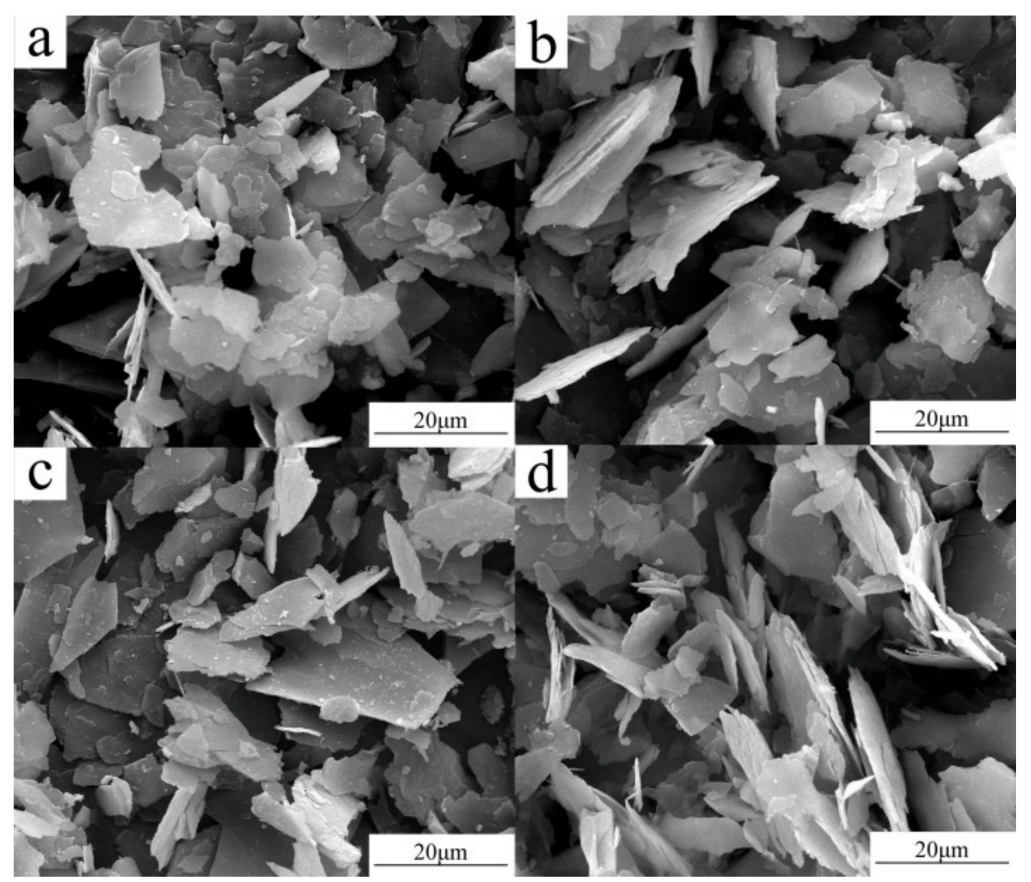

Figure 9. SEM images of (a) $\mathrm{S}_{0} ;(\mathbf{b}) \mathrm{S}_{1} ;$ (c) $\mathrm{S}_{2}$; and (d) $\mathrm{S}_{3}$. 


\section{Conclusions}

Activated sericite was prepared by thermal modification, acid activation, and sodium modification. The final product can be prepared by heating at $800^{\circ} \mathrm{C}$ for $1 \mathrm{~h}$, reacting with $5 \mathrm{~mol} / \mathrm{L}$ nitric acid at $95^{\circ} \mathrm{C}$ for $5 \mathrm{~h}$ and mixing with supersaturated solution of sodium chloride at $95^{\circ} \mathrm{C}$ for $3 \mathrm{~h}$. After modification, the mica-type phase persisted while its crystallinity decreased. The CEC of the final product can be enlarged from $7.42 \mathrm{mmol} / 100 \mathrm{~g}$ to $56.37 \mathrm{mmol} / 100 \mathrm{~g}$ meq/g. The activated sericite is much more suitable than raw sericite to prepare polymer-clay nanocomposites.

Author Contributions: Yu Liang and Hao Ding conceived and designed the experiments; Yu Liang performed the experiments and analyzed data; Yu wrote the paper. Sijia Sun and Ying Chen helped the experiments and analyzed data.

Conflicts of Interest: The authors declare no conflict of interest.

\section{References}

1. Kojima, Y.; Usuki, A.; Kawasumi, M.; Okada, A.; Fukushima, Y.; Kurauchi, T.; Kamigaito, O. Mechanical properties of nylon 6-nlay hybrid. J. Mater. Res. 1993, 8, 1185-1189.

2. Lebaron, P.C.; Wang, Z.; Pinnavaia, T.J. Polymer-layered silicate nanocomposites: An overview. Appl. Clay Sci. 1999, 15, 11-29.

3. Vaia, R.A.; Price, G.; Ruth, P.N.; Nguyen, H.T.; Lichtenhan, J. Polymer/layered silicate nanocomposites as high performance ablative materials. Appl. Clay Sci. 1999, 15, 67-92.

4. Giannelis, E.P. Polymer-layered silicate nanocomposites: Synthesis, properties and applications. Appl. Organomet. Chem. 1998, 12, 675-680.

5. Xu, R.; Manias, E.; Snyder, A.J.; Runt, J. New biomedical poly(urethane urea)-Layered silicate nanocomposites. Macromolecules 2001, 34, 337-339.

6. Messersmith, P.; Giannelis, E. Synthesis and barrier properties of poly(e-caprolactone)—layered silicate nanocomposites. J. Polym. Sci. A Polym. Chem. 1995, 33, 1047-1057.

7. Akin, O.; Tihminlioglu, F. Effects of organo-modified clay addition and temperature on the water vapor barrier properties of polyhydroxy butyrate homo and copolymer nanocomposite films for packaging applications. J. Polym. Environ. 2017, 25, 1-12. [CrossRef]

8. Nguyen, Q.; Ngo, T.; Tran, P.; Mendis, P.; Bhattacharyya, D. Influences of clay and manufacturing on fire resistance of organoclay/thermoset nanocomposites. Compos. Part A 2015, 74, 26-37.

9. Gilman, J.; Jackson, C.; Morgan, A.; Harris, R.; Manias, E.; Giannelis, E.; Wuthenow, M.; Hilton, D.; Phillips, S. Flammability properties of polymer-layered-silicate nanocomposites. Polypropylene and polystyrene nanocomposites. Chem. Mater. 2000, 12, 1866-1873.

10. Aranda, P.; Mosqueda, Y.; Perez-Cappe, E.; Ruiz-Hitzky, E. Electrical characterization of poly(ethylene oxide)—clay nanocomposites prepared by microwave irradiation. J. Polym. Sci. B Polym. Phys. 2003, 41, 3249-3263.

11. Ray, S.S.; Yamada, K.; Okamoto, M.; Ueda, K. Polylactide-layered silicate nanocomposite: A novel biodegradable material. Nano Lett. 2002, 2, 1093-1096.

12. Kaur, M.; Datta, M. Synthesis and characterization of biodegradable clay-polymer nanocomposites for oral sustained release of anti-inflammatory drug. Eur. Chem. Bull. 2013, 2, 670-678.

13. Lilichenko, N.; Maksimov, R.D.; Zicans, J.; Meri, R.M.; Plume, E. A biodegradable polymer nanocomposite: Mechanical and barrier properties. Mech. Compos. Mater. 2008, 44, 45-56.

14. Pavlidou, S.; Papaspyrides, C.D. A review on polymer-layered silicate nanocomposites. Prog. Polym. Sci. 2008, 22, 1119-1198.

15. Sahoo, S.; Manjaiah, K.M.; Datta, S.C.; Shabeer, T.P.A.; Kumar, J. Kinetics of metribuzin release from bentonite-polymer composites in water. J. Environ. Sci. Health Part B Pestic. Food Contam. Agric. Wastes 2014, $49,591-600$.

16. El-Hamshary, H.; Selim, A.I.; Salahuddin, N.A.; Mandour, H.S. Clay-polymer nanocomposite-supported brominating agent. Clays Clay Miner. 2015, 63, 328-336.

17. Choi, H.; Kim, S.; Hyun, Y.; Jhon, M. Preparation and rheological characteristics of solvent-cast poly(ethylene oxide)/montmorillonite nanocomposites. Macromol. Rapid Commun. 2001, 22, 320-325. 
18. Hackett, E.; Manias, E.; Giannelis, E.P. Molecular dynamics simulations of organically modified layered silicates. J. Chem. Phys. 1998, 108, 7410-7415.

19. Strawhecker, K.E.; Manias, E. Structure and properties of poly(vinyl alcohol)/ $\mathrm{Na}^{+}$montmorillonite nanocomposites. Chem. Mater. 2000, 12, 2943-2949.

20. Yano, K.; Usuki, A.; Okada, A.; Kuranchi, T.; Kamigaito, O. Synthesis and properties of polyimide clay hybrid. J. Polym. Sci. A Polym. Chem. 1993, 31, 2493-2498.

21. Ginzburg, V.; Balazs, A. Calculating phase diagrams for nanocomposites: The effect of adding end-functionalized chains to polymer/clay mixtures. Adv. Mater. 2000, 12, 1805-1809.

22. Manias, E.; Chen, H.; Krishnamoorti, R.; Genzer, J.; Kramer, E.J.; Giannelis, E.P. Intercalation kinetics of long polymers in $2 \mathrm{~nm}$ confinements. Macromolecules 2000, 33, 7955-7966.

23. Wang, L.; Chen, Z.; Wang, X.; Yan, S.; Wang, J.; Fan, Y. Preparations of organo-vermiculite with large interlayer space by hot solution and ball milling methods: A comparative study. Appl. Clay Sci. 2011, 51, 151-157.

24. Fonseca, M.G.D.; Wanderley, A.F.; Souea, K.; Arakaki, L.N.H.; Espinola, J.G.P. Interaction of aliphatic diamines with vermiculite in aqueous solution. Appl. Clay Sci. 2006, 32, 94-98.

25. Rey-Perez-Caballero, F.D.; Poncelet, G. Preparation and characterization of microporous 18 angstrom Al-pillared structures from natural phlogopite micas. Microporous Mesoporous Mater. 2000, 41, 169-181.

26. Williams-Daryn, S.; Thomas, R.K. The intercalation of a vermiculite by cationic surfactants and its subsequent swelling with organic solvents. J. Colloid Interface Sci. 2002, 255, 303-311.

27. Tjong, S.C.; Meng, Y.Z. Preparation and characterization of melt-compounded polyethylene/vermiculite nanocomposites. J. Polym. Sci. B Polym. Phys. 2003, 41, 1476-1484.

28. Tjong, S.C.; Meng, Y.Z.; Xu, Y. Structure and properties of polyamide-6/vermiculite nanocomposites prepared by direct melt compounding. J. Polym. Sci. B Polym. Phys. 2002, 40, 2860-2870.

29. Xu, J.; Meng, Y.Z.; Li, R.K.Y.; Rajulu, A.V. Preparation and properties of poly(vinyl alcohol)-vermiculite nanocomposites. J. Polym. Sci. B Polym. Phys. 2003, 41, 749-755.

30. Yu, X.; Ram, B.; Jiang, X. Parameter setting in a bio-inspired model for dynamic flexible job shop scheduling with sequence-dependent setups. Eur. J. Ind. Eng. 2007, 1, 182-199.

31. Ding, H.; Xu, X.; Liang, N.; Wang, Y. Preparation sericite nanoflakes by exfoliation of wet ultrafine grinding. Adv. Mater. Res. 2011, 178, 242-247.

32. Shih, Y.-J.; Shen, Y.-H. Swelling of sericite by LiNO(3)-hydrothermal treatment. Appl. Clay Sci. 2009, 43, 282-288.

33. Kim, J.-O.; Lee, S.-M.; Jeon, C. Adsorption characteristics of sericite for cesium ions from an aqueous solution. Chem. Eng. Res. Des. 2014, 92, 368-374.

34. Vaia, R.A.; Teukolsky, R.K.; Giannelis, E.P. Interlayer structure and molecular environment of alkylammonium layered silicates. Chem. Mater. 1994, 6, 1017-1022.

35. Valášková, M.; Barabaszová, K.; Hundáková, M.; Ritz, M.; Plevová, E. Effects of brief milling and acid treatment on two ordered and disordered kaolinite structures. Appl. Clay Sci. 2011, 54, 70-76.

36. Caseri, W.R.; Shelden, R.A.; Suter, U.W. Preparation of muscovite with ultrahigh specific surface-area by chemical cleavage. Colloid Polym.Sci. 1992, 270, 392-398.

37. Obut, A.; Girgin, I. Hydrogen peroxide exfoliation of vermiculite and phlogopite. Miner. Eng. 2002, 15, 683-687.

38. Rey-Perez-Caballero, F.D.; Poncelet, G. Microporous 18 angstrom Al-pilared vermiculites: Preparation and characterization. Microporous Mesoporous Mater. 2000, 37, 313-327.

39. Teng, H.; Zhu, G.; Huang, P.; Liu, P. Example analysis of orthogonal experimental design. Pharm. Care Res. 2008, 1, 75-76.

40. He, Z.; Liu, Y.; Chen, L.; Cao, M.; Xia, J. Orthogonal design-direct analysis for PCR optimization. Bull. Hunan Med. Univ. 1998, 4, 76-77.

41. Gates, W.P.; Komadel, P.; Madejova, J.; Bujdak, J.; Stucki, J.W.; Kirkpatrick, R.J. Electronic and structural properties of reduced-charge montmorillonites. Appl. Clay Sci. 2000, 16, 257-271.

(C) 2017 by the authors. Licensee MDPI, Basel, Switzerland. This article is an open access article distributed under the terms and conditions of the Creative Commons Attribution (CC BY) license (http://creativecommons.org/licenses/by/4.0/). 